\title{
Mass movement processes triggered by land subsidence in Iztapalapa, the eastern part of Mexico City
}

\author{
M. González-Hernández ${ }^{1}$, D. Carreón-Freyre ${ }^{2}$, R. Gutierrez-Calderon ${ }^{1}$, M. Cerca ${ }^{2}$, and \\ W. Flores-Garcia ${ }^{1}$ \\ ${ }^{1}$ Centro de Evaluación de Riesgos Geológicos CERG, Iztapalapa, Mexico City, Mexico \\ ${ }^{2}$ Centro de Geociencias de la UNAM, Juriquilla, Querétaro, Mexico \\ Correspondence to: D. Carreón-Freyre (freyre@geociencias.unam.mx)
}

Published: 12 November 2015

\begin{abstract}
Geological and structural conditions in the Basin of Mexico coupled with natural and anthropogenic factors, such as groundwater exploitation, provokes land subsidence and differential deformation. The study area is located in to the north of Iztapalapa, a municipality within Mexico City, in a site called "El Eden" with irregular topography. Where volcanic sequences overlie the lacustrine deposits of clays and silts and show displacements by the action of gravity. The displacement zone was delimited at the top of the slope by the formation of circular tensile fractures with stair -shaped geometries. At the base of the slope, compressive processes damaged housing, sidewalks and inclined light poles and trees. A NW-SE system of fractures was identified in which displacement velocities vary from a few millimeters to several centimeters per year. Which affects urban facilities. In this work a conceptual model of deformation is presented that integrates the geological and mechanical factors leading to landslide and land subsidence. A geophysical survey leads to evidence of how land subsidence processes increase the sliding slope.
\end{abstract}

\section{Introduction}

Mexico City (MC) is located within the Basin of Mexico, an endorheic basin whose morphology is the result of the interaction of volcanic and sedimentary processes. Nowadays the highest records of subsidence and ground fracturing are located at the northeast side of the city. More than $30 \%$ of the total surface has been damaged by processes related to the subsoil deformation within the Iztapalapa area. From a geomorphologic point of view the study area is comprised of three units (Fig. 1): (1) the highland, formed by volcanic deposits, (2) the slope zone, consisting of alluvial sequences and reworked volcanic deposits and (3) the lacustrine plain, formed by silty clayey sequences interbedded with fluvial and volcanic materials. In the zones 2 and 3, the geological conditions coupled with groundwater extraction, seismicity, static and dynamic loads, facilitate the development of land subsidence and ground fracturing, causing significant damage to urban infrastructure.

In Iztapalapa subsidence ranges from 10 to $40 \mathrm{~cm} \mathrm{year}^{-1}$ (López-Quiroz, 2009) and three systems of fracturing affect the $10 \%$ of its total surface (Carreón-Freyre, 2010). The study area called "El Eden", of about $0.15 \mathrm{~km}^{2}$, is located at the-northeast sector of Iztapalapa became highly damaged by localized deformation and fracturing. The subsoil is composed of sequences of volcanic materials from the Santa Catarina volcanic range, interbedded with pyroclastics, fluvial and lacustrine deposits (that correspond to the former Texcoco Lake). The topography is irregular and the volcanic sequences that overlie the lacustrine deposits of clays and silts displaced by the action of gravity. The movement zone was identified at the top of the slope by the formation of circular tensile fractures with stair shaped geometries.

At the base of the slope, compressive processes damaged housing, sidewalks and inclined light poles and trees. In this work a conceptual model of deformation is presented that integrates the geological and mechanical factors leading to landslide and land subsidence. The average depth of the contact zone and areas of fracturing and compression and a NWSE system of fractures are identified. 


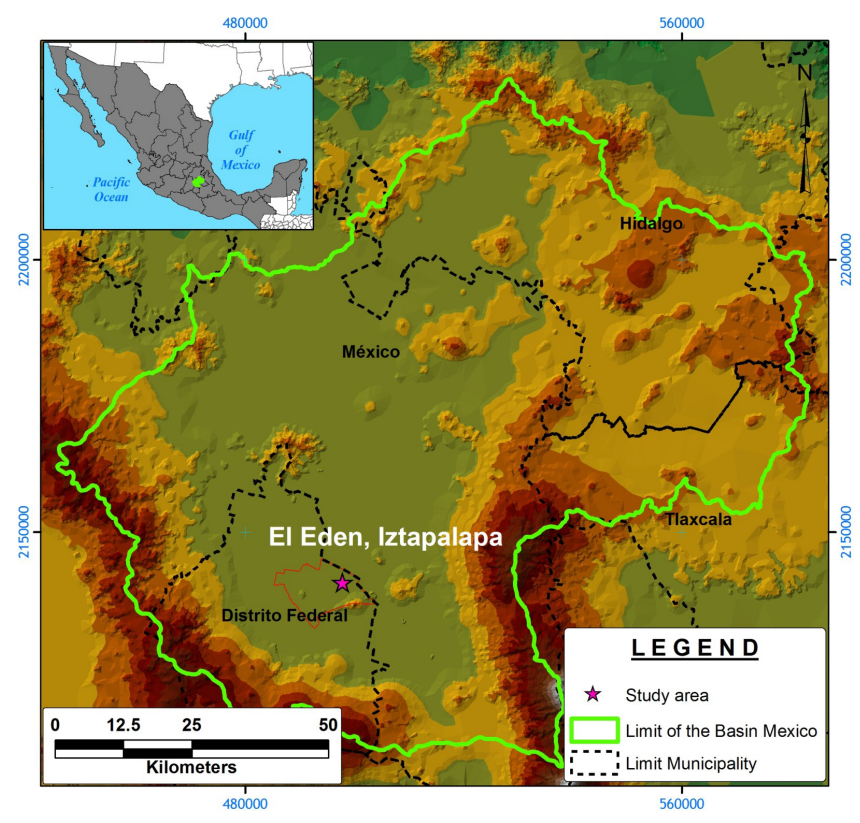

Figure 1. Location of the Mexico basin (in green) in the central part of Mexico. Whithin the Basin of Mexico is located the Mexico City (blackk dotted line, also called Distrito Federal) and the Iztapalapa municipality (red line). The location of "El Eden" Study Site is shown with a magenta star.

\section{Geological setting}

The morphological features of Mexico City are due to the interaction of faulting systems and volcanic activity from the Oligioceno to Miocene (Mooser at al., 1974). The subsoil is mainly composed of sedimentary rocks of the Upper Cretaceous, Tertiary and Quaternary volcanic and recent fluviolacustrine sequences. In the Iztapalapa zone higher structures correspond to volcanic buildings composed by andesites, basalts and pyroclastic rocks of the Pliocene-Pleistocene Santa Catarina Range, Cerro de la Estrella and Peñón del Marques. Along these structures the former Texcoco Lake covered the volcanic plain that was filled by lava flows, andesitic-basaltic pyroclastics (tuffs and ashes) as well as alluvial and lacustrine deposits (sand, silt and clays). From the mapping of subsidence and ground fracturing three main facture systems were identified in Iztapalapa: (a) the NESW system, aligned with the Santa Catarina Range (b) the WNW-ESE system aligned with the edge of Texcoco Lake and, (c) the system of tensile fractures surrounding the Peñon del Marqués (Fig. 2).

\section{Ground fracturing in slope areas of Iztapalapa}

Fractures mapped in Iztapalapa are concentrated around the border of the Santa Catarina Range and the Peñón del Marques volcano. These systems exhibit preferential directions of fracturing NE-SW and NW-SE, changes in the direction

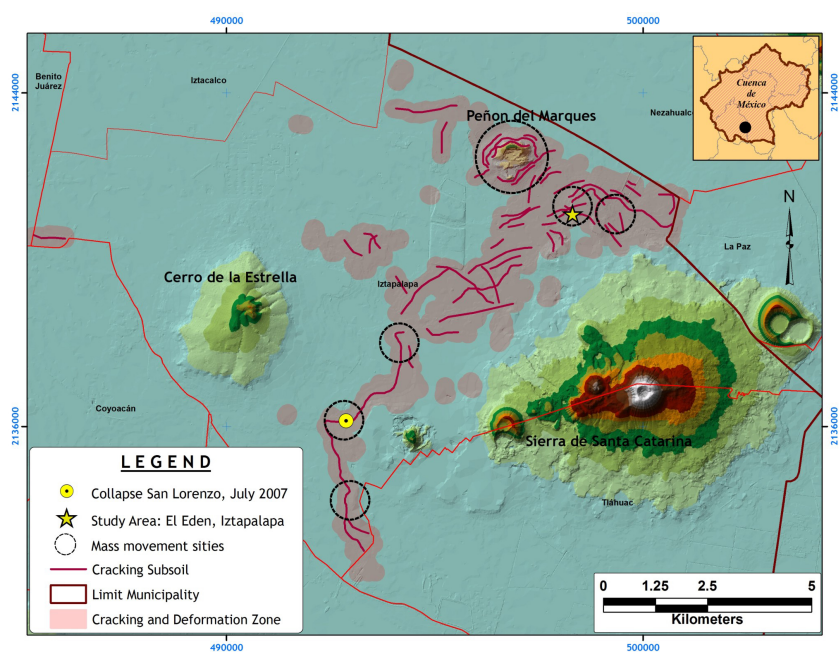

Figure 2. Detailed mapping of fracturing in Iztapalapa (red lines). The Santa Catarina Range is located to the south-eastern sector of Iztapalapa and the Peñon del Marques volcano is located to the north-east. Black circles correspond to the six indentified mass movements.

suggest that they are associated with the shoreline of the former Texcoco Lake and follow contacts between lake sediments (clays and silts) and buried lavas or pyroclastics (flow, surges and fall deposits) (Fig. 2). After mapping-in slope borders of the Santa Catarina range, six mass movement areas were identified. These areas are showing gravitational displacements that can be associated with the paleomorphology of the volcanic structures formed at the same period as Texcoco Lake, and that may be covered by volcanic-sedimentary deposits (Fig. 2).

In these areas slopes vary from 3 to $10^{\circ}$ and the volcanic deposits are often interbedded with fluvio-lacustrine sequences (Fig. 3). The lithological contacts become sliding planes that determine a lateral spreading and fracturing of the surface materials associated with vertical and/or horizontal displacements. The contrasting physical and mechanical properties of lacustrine sequences (low shear strength and high compressibility) and pyroclasts materials (non-plastic, porous and non-cohesive), the irregular topography and coupled with groundwater exploitation facilitates the development of land subsidence. This phenomenon causes gradual changes in the thicknesses of the lacustrine sequences in turn modifying the original slope, this condition trigger a gravity process of "mass movement" with orders of magnitude ranging from some $\mathrm{mm}$ to many $\mathrm{cm}$ per year. These "masses" displace overlying irregular surfaces that are lithological contacts and generates shear fissures between both geological materials. The morphological features of this phenomenon consist of tensile fractures in the upper zone, with variable length and irregular geometry, often concave, with significant vertical displacements ( 0.3 to $1 \mathrm{~m}$ in average). The stress fractures have variable length, opening and direction. While 


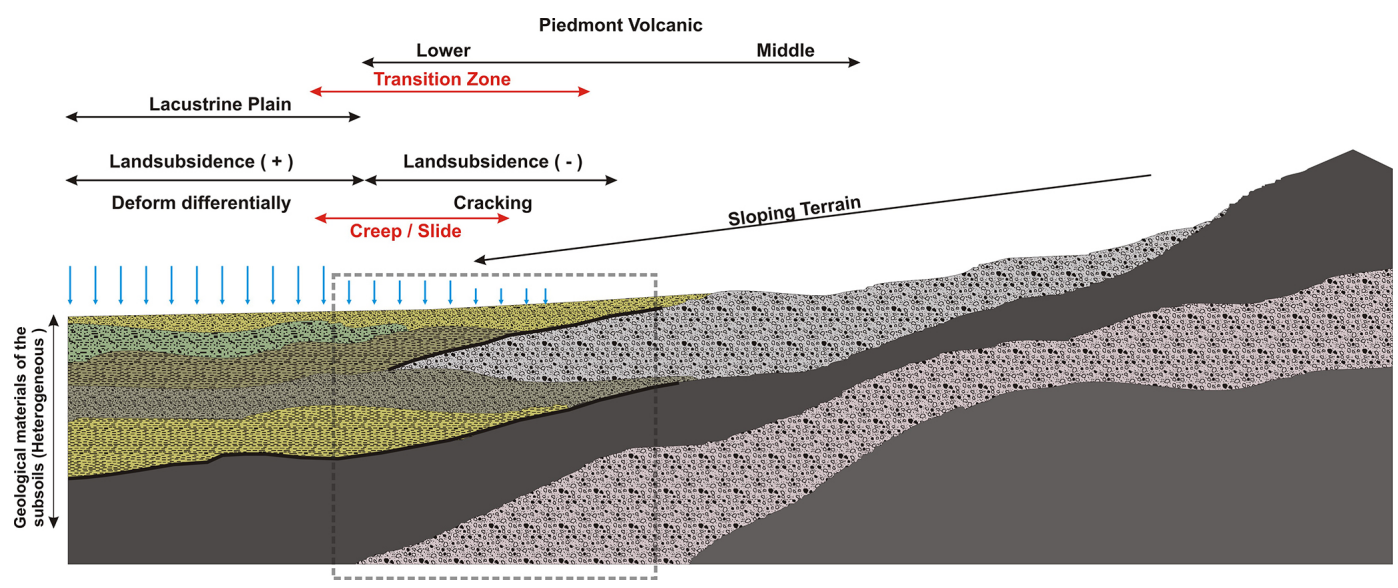

Figure 3. Schematic geological section of the piedmont zones in the Santa Catarina Range. Phenomena of land subsidence in the lacustrine plain (left) associated with mass movements processes (right) over a detachment surface are shown.

in the front area a compression process has been mapped by damage on sidewalks and walls, as well as distortion structural elements of houses. The depth of the lithological contact acting as a detachment surface depends on the fabric and morphology of the deposit (Fig. 3).

\section{Field mapping at "El Eden" study site}

From the six sites with identified mass movement processes, the site with the highest reported damage is called "El Eden", located at the northeast sector of Iztapalapa (Fig. 4). The subsoil sequence is composed by silty clays and volcanic deposits, lava and fall, identified through information collected from previous geotechnical boreholes and outcrops nearby the study area. The zones identified within "El Eden" mass movement are shown in the map of Fig. 4. The orange area, of about $38000 \mathrm{~m}^{2}$, corresponds to a tensile zone with NWSE stepped fractures spaced every $45 \mathrm{~m}$. The yellow area, of about $35000 \mathrm{~m}^{2}$, indicates a high deformed compressive zone. The levelling survey in the study site shows an irregular topography that can be associated with the paleomorphology of a buried volcanic structure, part of the same Santa Catarina Range. Altitude variations ranges from 0.5 to $8 \mathrm{~m}$ and slopes obtained by the interpolation of levelling points vary from 0 to $12^{\circ}$.

A geophysical survey was performed to characterize the subsurface structure. The 2-D MASW method was applied for obtaining $\mathrm{S}$ wave patterns, with the analysis variation of velocities of shear waves in depth, it was possible to identify the depth of lithological contacts and the thicknesses of the prospected layers. A $40 \mathrm{~m}$ length profile with an estimated penetration depth of $15 \mathrm{~m}$ is shown in Fig. 5. A sequence of 3 layers was characterized: (1) A high plasticity lacustrine clay, at a depth from 0 to $2 \mathrm{~m}$, with an $\mathrm{S}$ wave velocity less than $180 \mathrm{~m} \mathrm{~s}^{-1}$; (2) Black sands interbedded with silt and pyroclastic fall deposits, at depths from 2 to $6 \mathrm{~m}$ depth, with

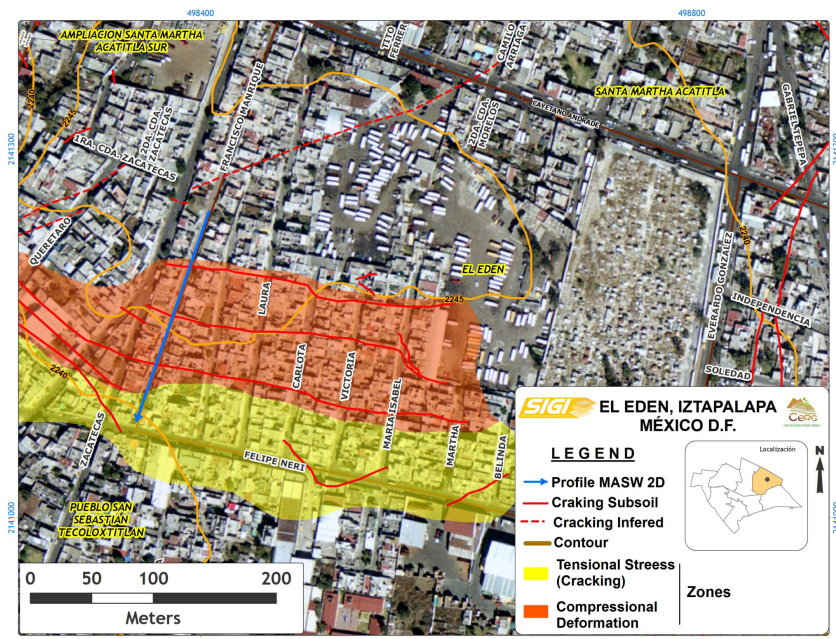

Figure 4. Location of "El Eden" Study Site in Iztapalapa. Orange colour indicate the tension area and the yellow colour the compressive area. Fractures are shown as red lines.

a s wave velocity varying than 180 to $300 \mathrm{~m} \mathrm{~s}^{-1}$; and, (3) fractured lava and pyroclastic flows with $\mathrm{S}$ wave velocities greater than $300 \mathrm{~m} \mathrm{~s}^{-1}$. The detachment surface of the mass movement was located a depth $3 \mathrm{~m}$.

\section{Conclusions}

Land Subsidence in the Iztapalapa area of Mexico City is associated with mass movement processes in the slope-area of the two main volcanic structures, the Santa Catarina Range and the Peñon del Marques volcano. Slope changes due to land subsidence in the lacustrine plains causes instability in areas where the subsoil is composed of high plasticity clays from Texcoco Lake, along with interbedded sandy and silty ashes and fractured lava flows. 


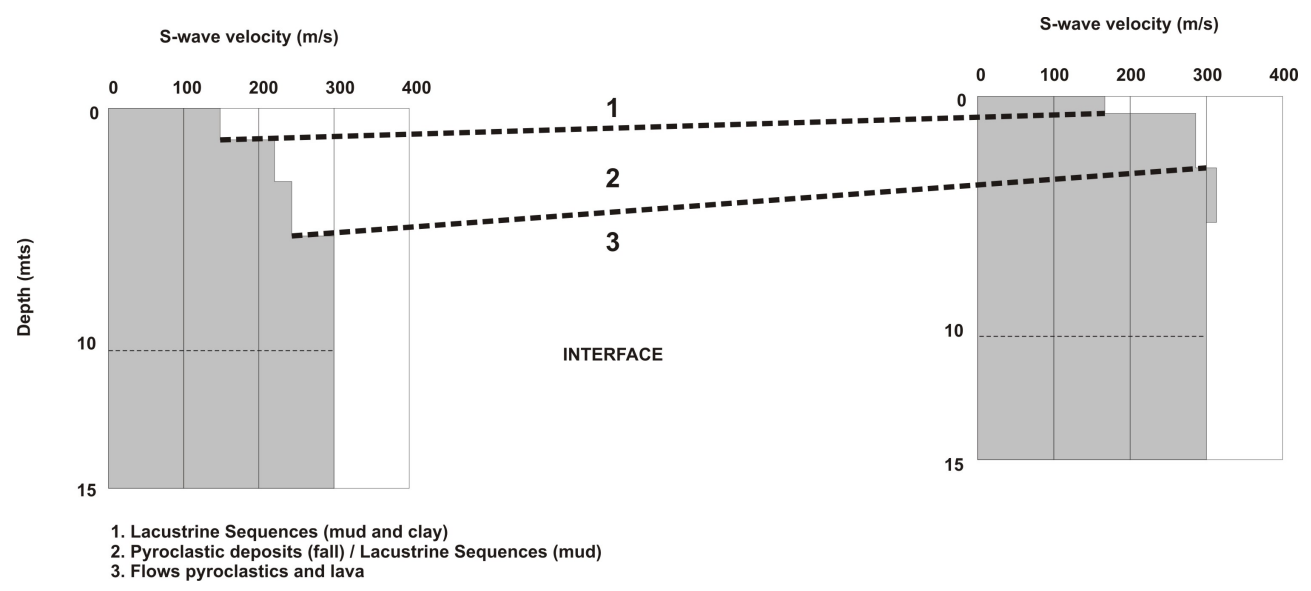

Figure 5. 1-D S-Wave velocities model from the 2-D MASW Method showing a $15 \mathrm{~m}$ depth of investigation. Three layer according to the shear velocities were identified (1) lacustrine clays, (2) sand, volcanic ashes; (3) volcanic flows and fractured lavas.

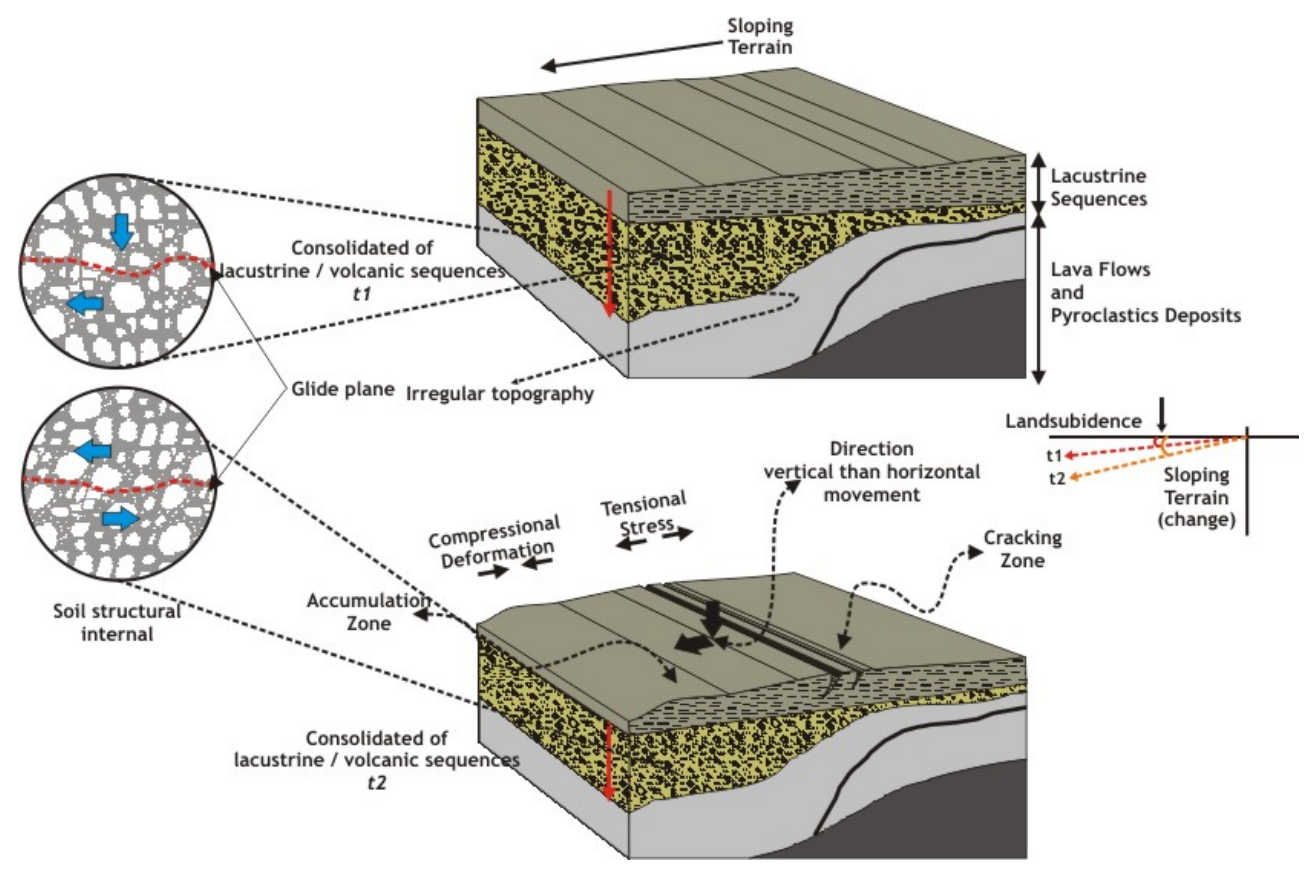

Figure 6. Conceptual model of the mass movement processes associated to land subsidence. (a) Initial conditions before consolidation of lacustrine sediments; (b) Mass movement showing the tension and compression zones in the upper and lower part of the slope respectively. Black arrows indicate the movement direction.

A conceptual model of the mass movement in the "El Eden" study site is presented (Fig. 6). A sliding slope was delimited into two strips, the upper zone and the front area. The upper zone is under tensional strees because of lateral spreading with stepped fracturing systems and parallel geometries. The front zone is under compressional stress causing significant damage to urban structures. The clayey layers behave as detachment surfaces that could be identified by the 2-D MASW method because of its low $S$ wave velocities.

The mass movements associated with land subsidence processes are of greatest importance in Iztapalapa because the damage caused to housing and urban facilities (roads and pipes), where the demaged area covers approximately $74000 \mathrm{~m}^{2}$.

Acknowledgements. The authors acknowledge the support of the DGAPA-UNAM research project No. IN114714 and, the field support of the staff from Centro de Evaluación del Riesgo Geológico (CERG): Cesar M. Tovar Medina, Enrique Luna Sánchez, Felix A. Centeno-Salas and Said R. Zacarías Ramírez. 


\section{References}

Carreón-Freyre, D.: Land subsidence processes and associated ground fracturing in Central Mexico, in: Land Subsidence, Associated Hazards and the Role of Natural Resources Development (Proceedings of EISOLS 2010, Querétaro, México), edited by: Carreón-Freyre, D., Cerca, M., and Galloway, D. L., Red Book Series Publication 339, IAHS Press, CEH Wallingford, UK, ISBN: 978-1-907161-12-4, ISSN: 0144-7815, 149-157, 2010.

López-Quiroz, P., Marie-Pierre Doin, M.-O., Tupin, F., Briole, P., and Nicolas, J.-M.: Time series analysis of Mexico City subsidence constrained by radar interferometry, J. Appl. Geophys., 69, 1-15, doi:10.1016/j.jappgeo.2009.02.006, 2009.
Mooser, F., Nairn, A. E. M., and Negendank, J. F. W.: Paleomagnetic investigations of the Tertiary and Quaternary igneous rocks: VIII A paleomagnetic and petrologic study of volcanics of the Valley of Mexico, Geologischen Rundschau, 63, 451-483, 1974. 